\title{
Variation in clearance and ingestion rates by larvae of the black-lip pearl oyster (Pinctada margaritifera, L.) feeding on various microalgae
}

\author{
M.S. DOROUDI, P.C. SOUTHGATE \& J.S. LUCAS \\ School of Marine Biology and Aquaculture, James Cook University, Townsville, Queensland, Australia
}

\begin{abstract}
Clearance rate (CR) and ingestion rate (IR) of different sizes (89, 125 and $188 \mu \mathrm{m}$ shell length) of Pinctada margaritifera larvae were determined when feeding on various microalgae. The microalgae tested were the diatoms, Chaetoceros mueller $i$ and $C$. simplex, and flagellates, Tahitian Isochrysis aff. galbana, Pavlova lutheri and P. salina at 5 or 10 cells $\mu \mathrm{L}^{-1}$. Both CR and IR of microalgae tested in this study increased with increasing larval size; but at all larval sizes, diatoms resulted in lower CR and IR. Of the microalgae tested, $P$. margaritifera larvae showed greatest $\mathrm{CR}$ and IR with the two Pavlova spp. Maximum CR for P. salina was 10.5, 21.2 and $29.7 \mu \mathrm{L} \mathrm{h}^{-1}$ for larvae with shell lengths of 89,125 and $188 \mu \mathrm{m}$, respectively. The highest IR values for $P$. margaritifera larvae with shell lengths of 89,125 and $188 \mu \mathrm{m}$ were 8.7, 81.0 and 165.7 cells $\cdot$ larva $^{-1} \mathrm{~h}^{-1}$, respectively. CR and IR of $P$. salina were approximately five times higher than those recorded for $C$. muelleri and $C$. simplex.
\end{abstract}

KEY WORDS: clearance, ingestion, larvae, microalgae, pearl oyster, Pinctada margaritifera

Received 2 January 2001, accepted 4 January 2002

Correspondence: Mehdi S. Doroudi, NSW Fisheries, C-Murray Irrigation, Wakool 2710, NSW, Australia. E-mail: doroudim@fisheries.nsw. gov.au

\section{Introduction}

Some research has suggested that temperate microalgae are unsuitable for rearing larvae of tropical pearl oysters because of the high water temperature at which the larvae are reared (Minaur 1969; Tanaka et al. 1970). Thus, Southgate et al. (1998) assessed the nutritional value of three species of tropical microalgae (Tahitian Isochrysis aff. galbana, Pavlova salina and Chaetoceros simplex) for larvae of Pinctada margaritifera. They reported significant differences in the nutritional value of the three species tested. The nutritional value of microalgae to bivalve larvae is influenced by many factors, including size, morphology and chemical composition. Particle capture by bivalve larvae depends on morphological characteristics of the larvae, such as length and velocity of the preoral cilia and the length of the velar edge (Strathmann \& Leise 1979; Gallager 1988; Riisgard et al. 2000).

Larval nutrition has an important role in maximizing larval growth and survival in bivalve hatcheries; however, there is a paucity of information on the nutrition of pearl oyster larvae. Clearly, clearance rate (CR) and ingestion rate (IR) of microalgae will have a major influence on the growth of bivalve larvae and, on this basis, it is important that the microalgae chosen as larval foods are readily ingested. However, no prior study has reported on the CR and IR of pearl oyster larvae feeding on different species of microalgae and how these vary with larval age. Therefore, this study examined the relative $\mathrm{CR}$ and IR of different ages of $P$. margaritifera larvae feeding on various species of microalgae (flagellates and diatoms).

\section{Materials and methods}

\section{Microalgae}

Microalgae starter cultures were obtained from CSIRO Fisheries Division in Hobart, Tasmania, and the codes below refer to CSIRO catalogue codes. Algae were cultured in 3-L glass flasks in autoclaved $0.45-\mu \mathrm{m}$-filtered and UV-treated seawater using $\mathrm{f} / 2$ nutrient medium (Guillard 1983). Algae were fed to larvae during the exponential growth phase. 


\section{Larval rearing}

Pinctada margaritifera larvae were reared in $500 \mathrm{~L}$ tanks according to the methods of Southgate \& Beer (1997). They were fed a $1: 1$ mixture of Tahitian Isochrysis aff. galbana clone T-ISO (CS 177) and P. salina (CS 49) at a density of 1-20 cells $\mu \mathrm{L}^{-1}$, based on previous studies with $P$. margaritifera larvae (Southgate \& Beer 1997; Doroudi et al. 1999). Larvae were taken from these cultures for use in experiments. Larvae were unfed for $24 \mathrm{~h}$ prior to the start of experiments to maximize CR and IR (Sprung 1985; Gallager 1988).

\section{Clearance and ingestion rates}

Larvae were transferred to triplicate $500 \mathrm{~mL}$ beakers at three different ages and sizes, 5 days $(89 \pm 3.1 \mu \mathrm{m}$ shell length, SL, $n=30), 10$ days $(125 \pm 10.4 \mu \mathrm{m} \quad \mathrm{SL}, n=30)$ and 20 days $(188 \pm 11.8 \mu \mathrm{m}$ SL, $n=30)$ after fertilization. Larvae were fed with one of five microalgae: T-ISO, Pavlova lutheri, P. salina, Chaetoceros muelleri and C. simplex, at a density of 5 or 10 cells $\mu \mathrm{L}^{-1}$. The higher microalgae density (10 cells $\mu \mathrm{L}^{-1}$ ) was only used for the older (188 $\mu \mathrm{m} \mathrm{SL}$ ) larvae. Experiments were conducted at $27^{\circ} \mathrm{C}$ and $34 \%$ salinity. Sufficient larvae $\left(20-30 \mathrm{~mL}^{-1}\right)$ were used in each experiment to achieve a marked reduction in algal density. A set of beakers with no larvae were used as controls to determine change in algal density independent of larval feeding. Samples $(20 \mathrm{~mL})$ were taken from each beaker at the start of the experiments and every $2 \mathrm{~h}$ thereafter, for a period of $6 \mathrm{~h}$. After removing larvae from these samples using a $25 \mu \mathrm{m}$ sieve, algal cells were counted using a Multisizer high speed particle counter Model II (Coulter Multisizer, Coulter, Fullerton, CA) fitted with a $70 \mu \mathrm{m}$ aperture tube.

CR was calculated from the following formula, which was modified from Lucas (1982) to include a correction factor from the control:

$$
\mathrm{CR}\left(\mu \mathrm{L} \text { larvae }^{-1} \mathrm{~h}^{-1}\right)=v\left[t^{-1} \ln \left(C_{0} / C_{t}\right)-a\right]
$$

where $v$ is the volume of water per larvae $(\mu \mathrm{L}), t$ the duration of experiment (h), $C_{0}$ the initial cell density (cells $\mu \mathrm{L}^{-1}$ ), $C_{\mathrm{t}}$ the final cell density (cells $\mu \mathrm{L}^{-1}$ ), and $a$ the correction factor from control

$$
\mathrm{a}\left(\mathrm{h}^{-1}\right)=t^{-1} \ln \left(C_{0} / C_{t}^{\prime}\right)
$$

where $C^{\prime}{ }_{t}$ is the final cell density in control (cells $\mu \mathrm{L}^{-1}$ ).

Weight-specific $\mathrm{CR}_{\mathrm{s}}\left(\mu \mathrm{L}^{-1} \mathrm{~L}^{-1}\right.$ ) was calculated using the following equation (Lu \& Blake 1997):

$$
\mathrm{CR}_{\mathrm{s}}=\mathrm{CR} / \mathrm{AFDW}
$$

where AFDW is the ash-free dry weight of larvae $(\mu \mathrm{g})$.
IR at any mean cell concentration, was obtained by the equation:

$\operatorname{IR}\left(\right.$ cells larvae $\left.{ }^{-1} \mathrm{~h}^{-1}\right)=\mathrm{CR}\left(\mu \mathrm{L}\right.$ larvae $\left.^{-1} \mathrm{~h}^{-1}\right) \times \bar{C}\left(\right.$ cells $\left.\mu \mathrm{L}^{-1}\right)$

where $\bar{C}$ is the mean cell concentration (cells $\mu \mathrm{L}^{-1}$ )

$$
=C_{0}-C_{t} / t[(\mathrm{CR} / v)+a]
$$

(Lucas 1982)

\section{Measurements and data analysis}

Shell length values of larvae were recorded from samples of 30 larvae using a graduated eyepiece in a microscope. AFDW values for larvae were obtained by collecting a known number of $P$. margaritifera larvae on a Whatman $\mathrm{GF} / \mathrm{C}$ filter, drying them at $60{ }^{\circ} \mathrm{C}$ for $48 \mathrm{~h}$ and ashing them in a furnace at $450{ }^{\circ} \mathrm{C}$ for $4 \mathrm{~h}$ (Epifanio 1979). Each analysis was conducted three times.

Two-way analysis of variance (ANOvA) was used to test the effect of microalgae species, body size and interaction between them on CR and IR. Statistical analyses were performed using the SPSS computer software.

\section{Results}

\section{Allometric relation}

The relationship between AFDW and SL for $P$. margaritifera larvae is expressed by the following allometric equation and is shown in Fig. 1:

$$
\mathrm{AFDW}=\left(1.5 \times 10^{-4}\right) \mathrm{SL}^{1.515}(r=0.91 ; n=6)
$$

As AFDW is related to volume, a three-dimensional unit $\left(\right.$ length ${ }^{3}$ ), while SL is a measure of length, an exponent of about 3 could be anticipated. However, the exponent in this allometric relationship was only about 1.5. Thus, AFDW, a measure of organic content of the larvae, declined relative to SL with increasing size (age) of the larvae. Either AFDW decreased relative to size as the larvae grew or there was a change in dimensions of the larvae such that SL increased relative to body width and height, or both these changes occurred.

\section{Clearance and ingestion rates}

$\mathrm{CR}$, IR and weight-specific $\mathrm{CR}_{\mathrm{s}}$ for larvae of $P$. margaritifera offered T-ISO, P. lutheri, P. salina, C. muelleri and C. simplex separately for a period of $6 \mathrm{~h}$ are shown in Figs 2-4, respectively. Maximum CR for each size of larvae occurred 


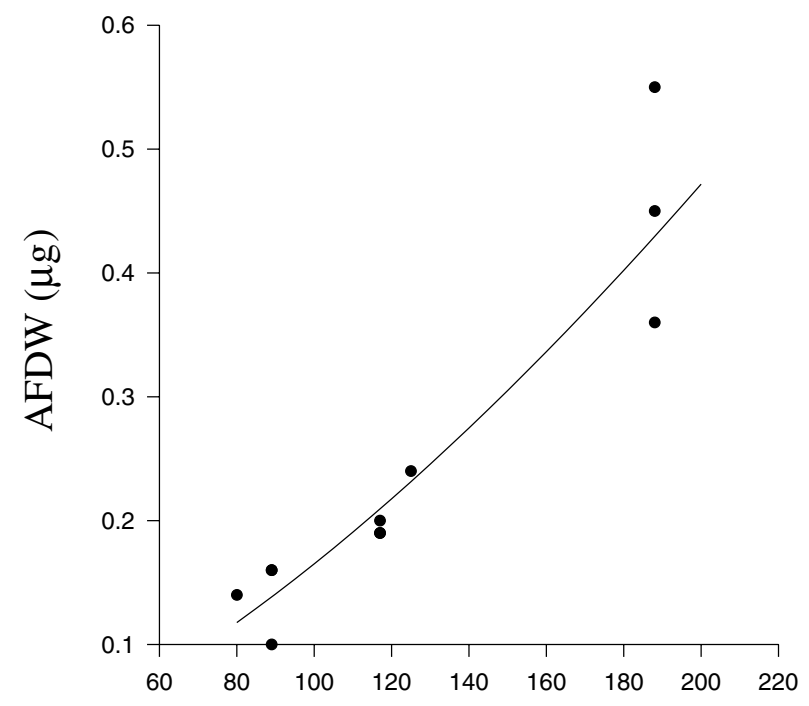

SL $(\mu \mathrm{m})$

Figure 1 Allometric relationships between ash-free dry weight $(\mathrm{AFDW}, \mu \mathrm{g})$ and shell length $(\mathrm{SL}, \mu \mathrm{m})$ in Pinctada margaritifera larvae.

when fed $P$. salina; these were $10.5,21.2$ and $29.7 \mu \mathrm{L}$ larvae $^{-1} \mathrm{~h}^{-1}$ for larvae with SL of 89,125 and $188 \mu \mathrm{m}$, respectively (Fig. 2). CR was next highest for larvae feeding on $P$. lutheri and then the other flagellate T-ISO. CR was lowest for the two diatoms (Chaetoceros spp.) at approximately $20-25 \%$ that of larvae feeding on $P$. salina. IR is related to CR and there was a similar pattern of high IR values for larvae feeding on $P$. salina with the lowest values for the diatoms (Fig. 3). The highest IR values for larvae of 89, 125 and $188 \mu \mathrm{m}$ SL were 8.7, 81 and 165.7 cells larvae $\mathrm{e}^{-1} \mathrm{~h}^{-1}$, respectively. Both $\mathrm{CR}$ and IR increased with larval size with all species of microalgae tested. This effect was most pronounced for IR and specifically for IR values for larvae feeding on the Pavlova spp. (Fig. 3). There was, however, no clear pattern of changing $\mathrm{CR}_{\mathrm{s}}$ with increasing larval size (Fig. 4).

Two-way ANOva showed that $\mathrm{CR}$ and IR varied significantly according to microalgae species $(P<0.01)$ and larval size $(P<0.01)$. CR and IR were significantly effected by type of microalgae (flagellates vs. diatoms), whereas they were not significantly different between the two Pavlova spp. or between the two Chaetoceros spp. There was a significant interaction $(P<0.01)$ between the effects of both microalgae species and larval size on CR and IR.

\section{Discussion}

This study showed that, of the five microalgae assessed, Pinctada margaritifera larvae showed more rapid CR and IR of flagellates (Pavlova spp. and T-ISO) when compared with the two diatoms (Chaetoceros spp.) tested. This is likely to reflect differences in cell size or shape between the flagellates and diatoms tested. The microalgae assessed in this study were in the range of 4-6 and 6-8 $\mu \mathrm{m}$ for flagellates and diatoms, respectively (based on measure-
Figure 2 Clearance rates $(\mu \mathrm{L}$ larvae $\mathrm{e}^{-1} \mathrm{~h}^{-1}$ ) for three developmental sizes $(89,125$ and $188 \mu \mathrm{m})$ of Pinctada margaritifera larvae feeding on various microalgae (Isochrysis T-ISO, Pavlova lutheri, P. salina, Chaetoceros muelleri and $C$. simplex).

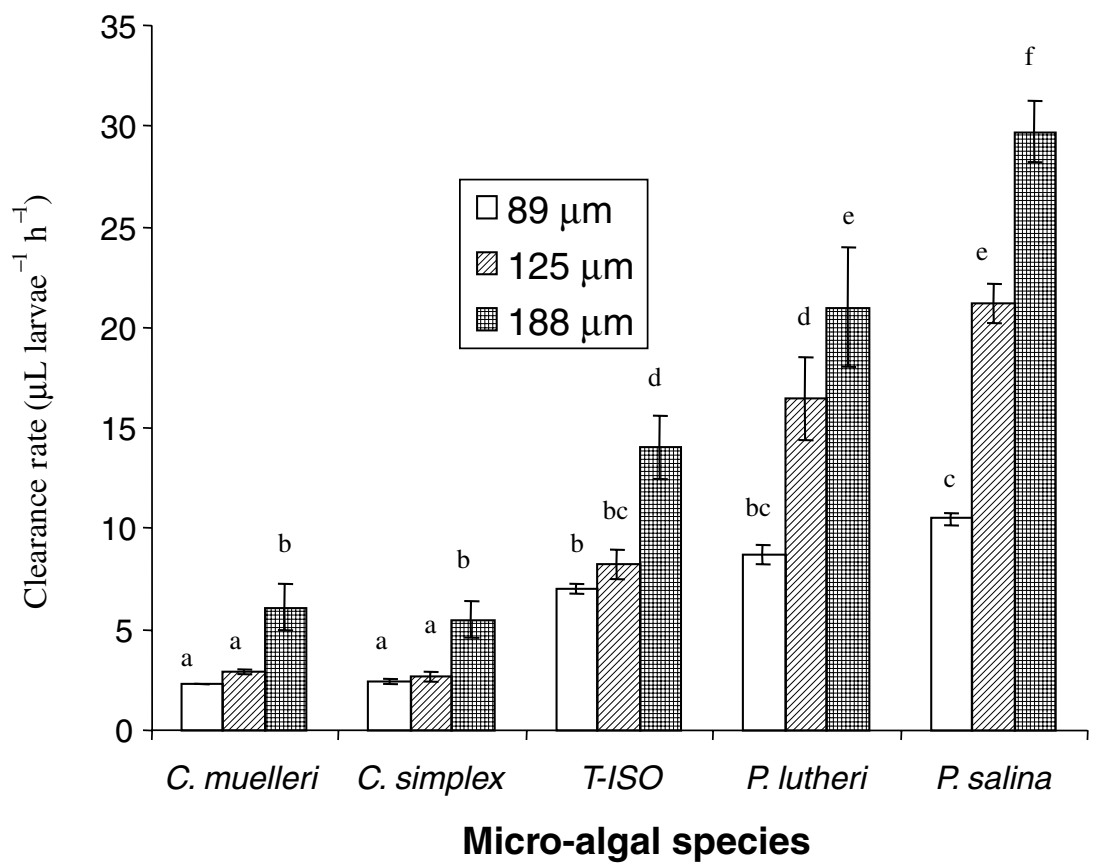



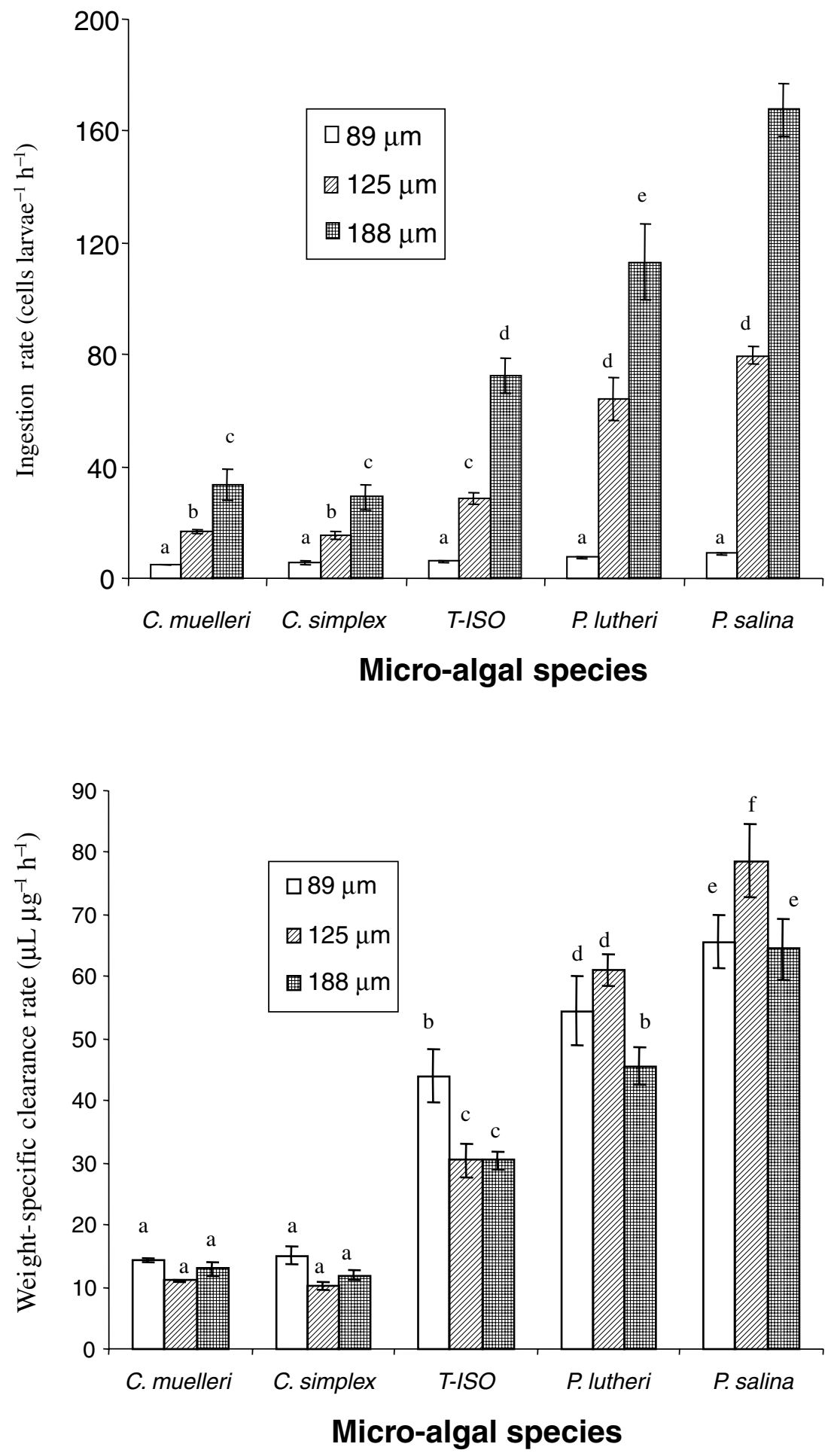

Figure 3 Ingestion rates (cells larvae $^{-1} \mathrm{~h}^{-1}$ ) for three developmental sizes $(89,125$ and $188 \mu \mathrm{m})$ of Pinctada margaritifera larvae feeding on various microalgae (Isochrysis T-ISO, Pavlova lutheri, P. salina, Chaetoceros muelleri and $C$. simplex).

\begin{abstract}
Figure 4 Weight specific clearance rates $\left(\mathrm{mL} \mu \mathrm{g}^{-1} \mathrm{~h}^{-1}\right)$ for three developmental sizes $(89,125$ and $188 \mathrm{~mm}$ ) of Pinctada margaritifera larvae feeding on various microalgae (Isochrysis T-ISO, Pavlova lutheri, P. salina, Chaetoceros muelleri and $C$. simplex).
\end{abstract}

ment using a multisizer). Riisgard et al. (1980) and Sprung (1985) concluded that, within a range of 1-9 $\mu \mathrm{m}$, Mytilus edulis larvae showed maximum $\mathrm{CR}$ of $3 \mu \mathrm{m}$ particles. The major difference between flagellates and diatoms is that the latter has spines (Hoff \& Snell 1987) which may make diatoms more difficult to capture and ingest using a ciliary system. Nevertheless, diatoms are widely used in diets for bivalve larvae (Brown et al. 1989) and information on their 
relative $\mathrm{CR}$ and $\mathrm{IR}$ is important in developing more efficient diets.

Of the flagellates assessed in this study, Pavlova spp. showed significantly greater CR and IR than T-ISO. In a similar study with Pteria sterna, microscopic observations showed the gut to contain relatively more $P$. lutheri than Isochrysis galbana when larvae were fed equal mixture of both species (Araya-Nunez et al. 1995). The preferential ingestion of Pavlova in this study and the high CR and IR recorded in the present study may reflect morphological differences between Pavlova spp. and T-ISO or differences in the 'taste' of algae (O'Meley \& Daintith 1992) reflecting differences in biochemical composition (Brown et al. 1997). Bayne et al. (1977) suggested that higher retention of Phaeodactylum tricornutum by $M$. edulis larvae may be a function of its cell shape and structure. Differences between the CR of Pavlova and T-ISO, which have a similar cell size, imply independent control over particle capture. Gallager (1988) reported that selection at the mouth in bivalve larvae, which could be passive or active, is a reason for differences in CR between Synechococcus and T-ISO by larvae of Mercenaria mercenaria.

CR of all species of microalgae tested increased with increasing larval size. Similarly, Wilson (1980) reported that CR increased with increasing size of Ostera edulis larvae. However, Gallager (1988) reported that rapid CR of smaller microalgae might be particularly significant for younger larvae where the diameter of the oesophagus and volume of the gut may limit the size and number of particles ingested. This might be expected, given that there is little change in the function of the filter-feeding system of bivalves larvae before metamorphosis to spat (Hickman \& Gruffydd 1971) and the result of this study showed that larval size had no effect on microalgae preference during larval development.

The results of this study have shown that the CR and IR of $P$. margaritifera larvae feeding on the flagellates T-ISO and $P$. salina are high. Based on these results, and those of Southgate et al. (1998) who showed T-ISO and P. salina to be of high nutritional value for $P$. margaritifera larvae, a combination of T-ISO and $P$. salina is likely to be a suitable diet for $P$. margaritifera larvae. It should be noted that $P$. lutheri was ingested to a greater degree than T-ISO and at a similar rate to $P$. salina. However, previous research with pearl oyster larvae has shown that $P$. lutheri, a temperate species with high nutritional value (Jeffrey et al. 1990), is unsuitable for rearing larvae of tropical bivalves at relatively high water temperatures (Minaur 1969; Tanaka et al. 1970).

\section{Acknowledgements}

We thank Dr David Klumpp for facilities at the Australian Institute of Marine Science and for advice during this study. Mr Robert Mayer, Queensland Department of Primary Industries and Dr Sjaak Lemmens of Brown and Root Co. Pty. Ltd. provided helpful comments on the manuscript. This study was funded by the Australian Center for International Agricultural Research (ACIAR) as part of Project Number FIS/97/31 'Pearl Oyster Resource Development in the Pacific Islands'.

\section{References}

Araya-Nunez, O., Ganning, B. \& Buckle-Ramirez, F. (1995) Embryonic development, larval culture and settling of American pearl-oyster (Pteria sterna, Gould). Calif. Fish Game, 81, 10-21.

Bayne, B.L., Widdows, J. \& Newell, R.I.E. (1977) Physiological measurements on estuarine bivalve molluscs in the field. In: Biology of Benthic Organisms (Keegan, B.F., O'Ceidigh, P. \& Boaden, P.J.S. eds), pp. 57-68. Pergamon Press, Oxford, UK.

Brown, M.R., Jeffrey, S.W. \& Garland, C.D. (1989) Nutritional Aspects of Microalgae Used in Mariculture; A Literature Review. CSIRO Marine Laboratories Report 205, CSIRO, Australia.

Brown, M.R., Jeffrey, S.W., Volkman, J.K. \& Dunstan, G.A. (1997) Nutritional properties of micro-algae for mariculture. Aquaculture, 151, 315-331.

Doroudi, M.S., Southgate, P.C. \& Mayer, R.J. (1999) The combined effects of temperature and salinity on embryos and larvae of the black-lip pearl oyster, Pinctada margaritifera (Linnaeus). Aquaculture Res., 30, 1-7.

Epifanio, C.E. (1979) Growth in bivalve molluscs: nutritional effects of two or more species of algae in diets fed to the American oyster, Crassostrea virginica (Gmelin) and the hard clam Mercenaria mercenaria (L.). Aquaculture, 18, 1-12.

Gallager, S.M. (1988) Visual observations of particle manipulation during feeding in larvae of a bivalve mollusc. Bull. Mar. Sci., 43, 344-365.

Guillard, R.L. (1983) Culture of phytoplankton for feeding marine invertebrates. In: Culture of Marine Invertebrates (Berg, C.L. ed.), pp. 108-132. Hutchinson Ross Publishing Co., Stroudberg, PA.

Hickman, R.W. \& Gruffydd, L.D. (1971) The histology of the larvae of Ostrea edulis during metamorphosis. In: Proceedings of the 4th Eur. Mar. Biol. Symp. (Crisp, D.J. ed.), pp. 281-249. Cambridge University Press, Cambridge, UK.

Hoff, F.H. \& Snell, T.W. (1987) Plankton Culture Manual. Florida Aqua Farms Inc, Florida, USA.

Jeffrey, S.W., Garland, C.D. \& Brown, M.R. (1990) Microalgae in Australian Mariculture. In: Biology of Marine Plants (Clayton, M.N. \& King, R.J. eds), pp. 400-414. Longman Cheshire Pty Ltd, Melbourne, Australia.

Lu, Y.T. \& Blake, N.J. (1997) Clearance and ingestion rates of Isochrysis galbana by larval and juvenile bay scallops, Argopecten irradians concentricus (Say). J. Shellfish Res., 16, 47-54.

Lucas, J.S. (1982) Quantitative studies of feeding and nutrition during larval development of the coral reef asteroid Acanthaster planci (L.). J. Exp. Mar. Biol. Ecol., 65, 173-193. 
Minaur, J. (1969) Experiments on the artificial rearing of the larvae of Pinctada maxima (Jameson) (Lamellibranchia). Aust. J. Mar. Freshwater Res., 20, 175-187.

O'Meley, C. \& Daintith, M. (1992) Algal cultures for marine hatcheries. A Hands-on Training Workshop, June 28-July 21992. Key Center for Teaching and Research in Aquaculture, University of Tasmania, Launceston, Tasmania.

Riisgard, H.U., Randlov, A. \& Kristensen, P.S. (1980) Rates of water processing, oxygen consumption and efficiency of particle retention in veligers and young post-metamorphic Mytilus edulis. Ophelia, 19, 37-47.

Riisgard, H.U., Nielsen, C. \& Larsen, P.S. (2000) Downstream collecting in ciliary suspension feeders: the catch-up principle. Mar. Ecol. Prog. Ser., 207, 33-51.

Southgate, P.C. \& Beer, A.C. (1997) Hatchery and early nursery culture of the black-lip pearl oyster (Pinctada margaritifera, L.). J. Shellfish Res., 16, 561-568.
Southgate, P.C., Beer, A.C., Duncan, P.F. \& Tamburri, R. (1998) Assessment of the nutritional value of three species of tropical microalgae, dried Tetraselmis and a yeast-based diet for larvae of the black-lip pearl oyster, Pinctada margaritifera (L.). Aquaculture, 162, 247-257.

Sprung, M. (1985) Physiological energetics of mussle larvae Mytilus edulis. II. Food uptake. Mar. Ecol. Prog. Ser., 17, 295-305.

Strathmann, R.R. \& Leise, E. (1979) On feeding mechanisms and clearance rates of molluscan veligers. Biol. Bull., 157, 524-535.

Tanaka, Y., Ito, H. \& Yushikazu, K. (1970) Basic research on production of Pinctada margaritifera nursery stock in Okinawa. II. Selection of feed organisms. Bull. Tokai Reg. Fish. Res. Lab., 63, 79-85.

Wilson, J.H. (1980) Particle retention and selection by larvae and spat of Ostrea edulis in algal suspensions. Mar. Biol., 57, $135-145$. 